\title{
The influence of litho- and pedogenic processes on Luvisols formation of selected area of Vistula Glaciation
}

\author{
Hanna JAWORSKA ${ }^{1, *}$, Halina DĄBKOWSKA-NASKRĘ ${ }^{1}$ and Mirosław KOBIERSKI ${ }^{1}$ \\ 1 University of Technology and Life Sciences, Faculty of Agriculture and Biotechnology, Department of Soil Science and Soil \\ Protection, Bernardyńska 6, 85-029 Bydgoszcz, Poland
}

\begin{abstract}
Jaworska, H., Dąbkowska-Naskręt, H., Kobierski, M., 2014. The influence of litho- and pedogenic processes on Luvisols formation of selected area of Vistula Glaciation. Geological Quarterly, 58 (4): 685-694, doi: 10.7306/gq.1175

The objective of the study was to determine the effect of litho- and pedogenic processes on soils of the selected area of Vistula Glaciation, based on profile distribution of unweathered components such as titanium, zirconium and silica in relation to their morphology, mineralogy, micromorphology and physicochemical properties. The predominant type of soil in the study area are Luvisols. Analysis of texture allowed to classify the investigated soils to sandy silts with loamy material as their subsoil. In the bulk soil silica dominates and its content was in the range 71.4 to $88.6 \%$. The content of $\mathrm{TiO}_{2}$ within the profiles is fairy similar, without clear patterns in the profile distribution. The total content of zirconium in the samples was in range of 95.13 to $212.15 \mathrm{mg} \mathrm{kg}^{-1}$. In the profile distribution of zirconium higher content of $\mathrm{Zr}$ was observed in the upper horizons compared to the top layer in all of the analysed profiles, indicating different origin of soil material. Statistical analysis showed positive correlation between the total content of zirconium and the content of fraction $\varnothing 0.05-0.002 \mathrm{~mm}$ (correlation coefficient value: 0.692384 ; significance level $-p<0.05$ ) and negative correlation between zirconium and clay content (correlation coefficient: $-0.668157 ; p<0.05)$. The lithologic discontinuity within profiles of the investigated soils has been additionally has proved by X-ray analysis of the clay fraction. The micromorphological analysis confirmed the complex genesis of the studied soils. The results of the study clearly showed an overall inhomogeneity and stratification of the soils. Studied Luvisols did not form as weathering product of homogeneous bedrock. Changes in granulometric and chemical composition within soil profiles are the consequence of translocation of clay fraction during lessivage as well as lithologic discontinuity of the solum.
\end{abstract}

Key words: Luvisols, lithological discontinuity, lessivage, glacial sediments.

\section{INTRODUCTION}

On the early post-glacial area, covered by Vistula Glaciation sediments, significant areas of soil covers with variation in morphology within soil profile occur. These soils were formed from the parent materials deposited during the Poznań Phase and Kujawy-Dobrzyń Subphase of the Vistula Glaciation (Fig. 1). Date ranges for the Poznań Phase and Kujawy-Dobrzyń Subphase are 18.4 ka BP (Wysota et al., 2008). The predominant type of soil in the study area are Luvisols (Skłodowski and Bielska, 2009; Mapa Gleb Polski 1:300,000, 1961). The main soil forming process is lessivage - that is vertical translocation of fine particles from a superficial horizon called the eluvial horizon, or E horizon, to another horizon, called the illuvial or B horizon. Luvisols exhibit the following genetic horizon sequence: Ap-Et-Bt-C. Texture of the soil material and the morphology of soil pedons suggest lithological non uniformity within soil profiles in the region. Possibly the main pedogenic process-translocation of clay fraction during the soil formation im-

* Corresponding author, e-mail: hanna.jaworska@utp.edu.pl

Received: April 30, 2013; accepted: March 24, 2014; first published online: June 18, 2014 pacted and altered changes caused by lithological discontinuity. Such a scenario of processes has to be checked by studying soil material composition.

There is a number of parameters that have been used to detect the presence of lithological discontinuity in soils: heavy minerals content (Chapman and Horn, 1968), morphology of sand particles (Schaetzl and Mokoma, 1998), clay mineralogy (Kuzila, 1995) formulas involving particle size fractions (Creemens and Mokma, 1986) and the change in the content of resistant minerals (Kuzila, 1995). The distribution of unweathered components within soil profile such as titanium, zirconium and silica can also prove parent material uniformity (Chapman and Horn, 1968; Semmel, 2004). Transformations of soil cover, as a result of pedogenic and geogenic processes, may be also defined in soils based on chemical composition of soil, or by mineralogical composition. This analysis should be applied to parent material of the investigated soils and its weathering products (Komisarek, 2000).

The study was undertaken to determine the effect of lithoand pedogenic processes on soil cover of the selected area of Vistula Glaciation (Weichselian), based on profile distribution of unweathered components such as titanium and zirconium, in relation to the morphology, micromorphology, mineralogy of clay fraction and chemical composition of bulk soils. The particularly important was to determine the depth of boundary between materials of different origin in the pedon and to asses if 


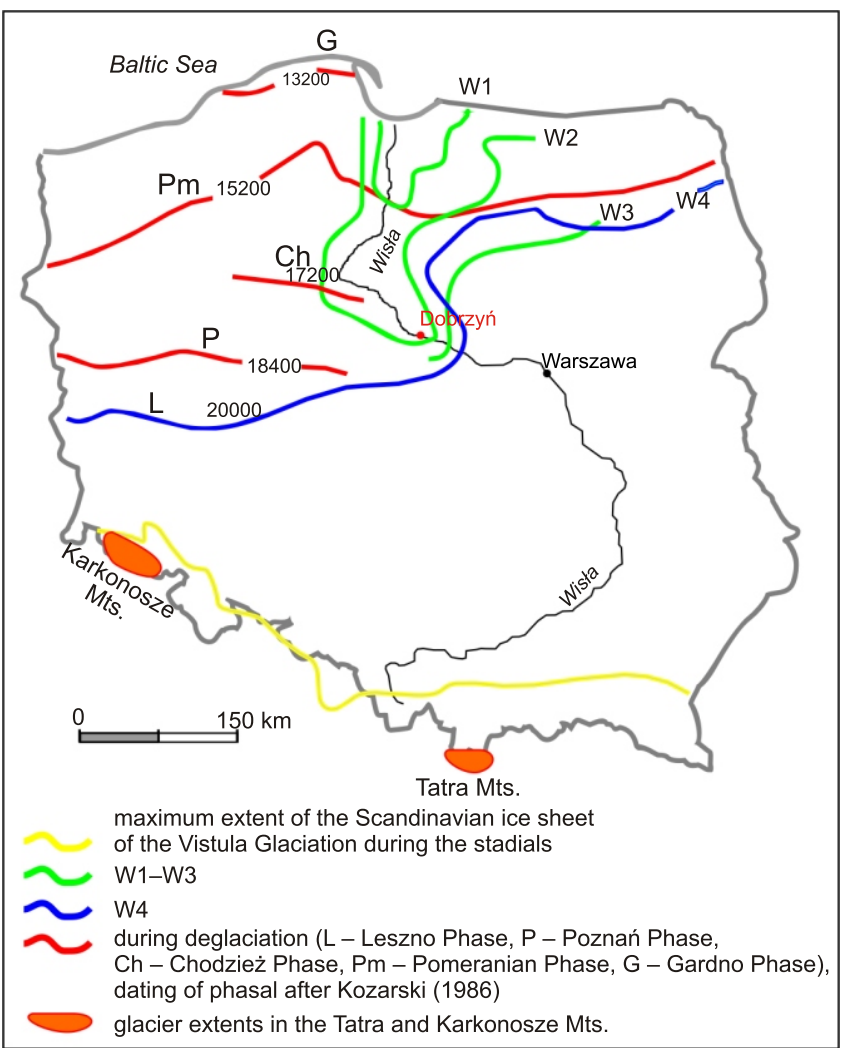

Fig. 1. Maximum extent of Pleistocene glaciations and ice sheet extents during stadials and phases of the Vistula Glaciation in Poland (according to Lindner and Marks, 1996) the textural and compositional differences between the two parts of solum are due strictly to pedogenic processes or represent actual lithologic and pedogenic differences within profiles. The results of the study will help to understand landscape evolution and near surface hydrology in this region.

\section{MATERIALS AND METHODS}

For the study seven profiles of Luvisols, formed from silty material underlain by till and located on the area of Pojezierze Południowopomorskie region (Poland), were chosen (Kondracki, 2002). Selected profiles were located on the flat area of ground moraine plane formed during the Poznań Phase of the Vistula Glaciation, (Galon, 1972; Lindner, 1984; Marks, 2002). Studied Luvisols are under argicultural use. The morphology of soil profiles was characterized according to Polish Soil Classification (2011). The colour of soil horizons was described using Munsell Color Soil Charts (1994). Soil samples were taken from each genetic horizon of profiles (Fig. 2). In the dried and sieved material of earth fraction with diameter $\varnothing<2.0 \mathrm{~mm}$ the following properties were determined: texture with the Casagrande aerometric method, modified by Prószyński (Polish Norm PN-ISO 11277, 2005) the content of fine clay fraction $(\varnothing<0.0002 \mathrm{~mm}$ ) was determined by centrifugation. Interpretation of the texture was performed according to Polish Soil Classification (2011: anex no. 3) and USDA (Soil Survey Staff, 2010) classification. Soil pH was measured in $\mathrm{H}_{2} \mathrm{O}$ and $1 \mathrm{MKCl}$ solution using a $1: 2.5 \mathrm{w}: \mathrm{v}$ soil/solution ratio on PHM 84 Radiometer. Organic $\mathrm{C}$ was determined by dichromate oxidation (Jackson, 1973) and total carbonate with the Scheibler apparatus. The total content of zirconium in the

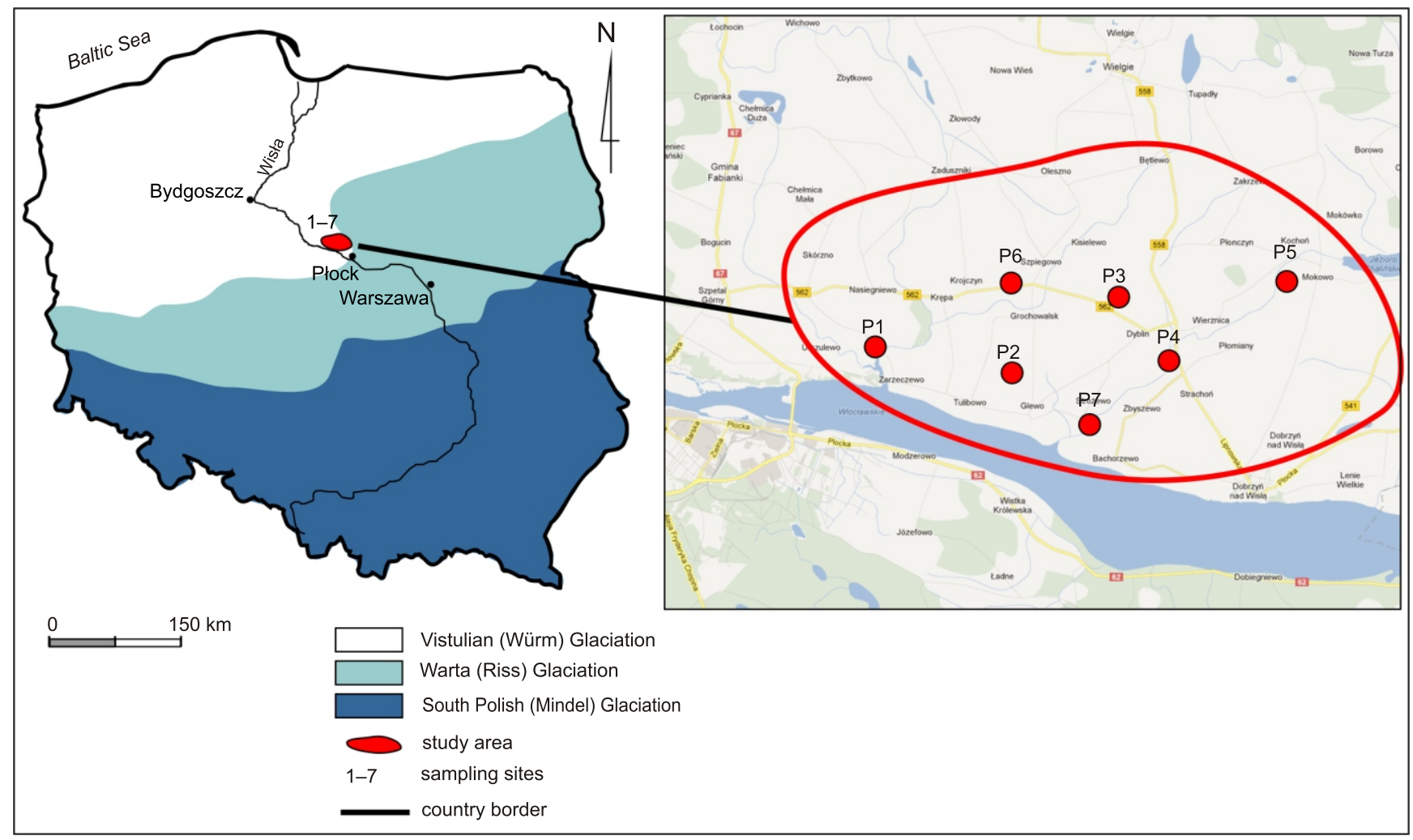

Fig. 2. Location of study area and sampling sites

P1 - Zarzeczewo, P2 - Glewo, P3 - Dyblin, P4 - Strachoń, P5 - Mokowo, P6 - Grochowalsk, P7 - Bachorzewo 
soil samples was determined by the fusion of soil with potassium pyrosulphate and its concentration in the solutions was determined with the spectrofluorimeter Hitachi F-2000 according to Wan et al. (2000). The contents of Ti were determined after digestion in Teflon beakers with a mixture of concentrated $\mathrm{HF}$ and $\mathrm{HClO}_{4}$ acids (Crock and Severson, 1980), by colorimetric method with tiron (Jackson, 1973). The results obtained were verified based on the Till-3 reference material (Geochemical Soil and Till Reference Materials certified by Breitländer Company). Changes in the oxides content within soil profile were evaluated on the basis of formulas given by Breemen and Buurman (1998), and Muhs et al. (2001).

For X-ray diffraction analysis $(\mathrm{XRD})$ clay fraction $(<0.2 \mu \mathrm{m})$ was separated according to Jackson (1973) procedure. Clay suspensions were treated with $30 \% \mathrm{H}_{2} \mathrm{O}_{2}$ at $70-80^{\circ} \mathrm{C}$ to oxidize organic material. Free iron oxides were removed by the $\mathrm{Na}$-citrate-bicarbonate dithionite method. The samples were dispersed with Na-amberlite. Clay samples were saturated with $\mathrm{Mg}$ and $\mathrm{K}$ and prepared on glass slides for $\mathrm{X}$-ray diffraction analysis. The air-dried Mg-saturated samples were analysed at $25^{\circ} \mathrm{C}$ followed by ethylene glycol solvation. The air-dried K-saturated samples were analysed at $25^{\circ} \mathrm{C}$ and then heated at $550^{\circ} \mathrm{C}$. XRD analyses were performed using a $X^{\prime}$ Pert Powder diffractometer operating at $40 \mathrm{KV}$ and $30 \mathrm{~mA}$ with CuK $\alpha$ radiation. Orientated clay slides were scanned in the range $2-30^{\circ} 2 \theta$ at the rate of $0.05^{\circ} 2 \theta \mathrm{min}^{-1}$. Semi-quantitative estimates of the proportions of the clay minerals were derived from peak area measurements (Brindley, 1980). Undisturbed soil samples were collected for micromorphological analyses. The thin sections were prepared following the standard procedure (FitzPatrick, 1984). To describe the thin sections, the Stoops (2003) terminology was used.

Statistical evaluation of results was performed using Statistica 10 software by setting Pearson's linear correlation coefficients.

\section{RESULTS AND DISCUSSION}

Morphological features of the soils are presented in Figure 3. They presented the following genetic horizon pattern: Ap-Et-Bt-C. The feature which differentiated the soils is the variation in the thickness of diagnostic horizons: Et and Bt, across the profiles, which suggests a varied intensity of the illuvial process affecting the soils investigated.

Analysed soils are characterized by relatively low humus content, with organic carbon in the range of 8.29 to $12.98 \mathrm{~g} \times$ $\mathrm{kg}^{-1}$. Investigated profiles are classified as soils with low content of $\mathrm{CaCO}_{3}$ occurring only in parent material and ranging from trace amounts to $4.4 \%$ (Appendix $1^{*}$ ). In terms of $\mathrm{pH}$, soils are in range 5.5-8.0 (Appendix 1). Lower values of $\mathrm{pH}$ were observed in surface horizons. Hydrolytic acidity varied in a profile (Appendix 1) and usually decreases along with depth with the highest values in humus horizons (excluding P2 profile).

Analysis of texture (Appendix 2) allows to classify the investigated soils to sandy silts with loamy material as their subsoil. Generally, surface horizons contain $20-55 \%$ of silt fraction with $\varnothing 0.05-0.002 \mathrm{~mm}$, which corresponds to sandy silt texture. Bt horizons and parent material contain $16-52 \%$ of fraction with $\varnothing 0.05-0.002 \mathrm{~mm}$ and $4-29 \%$ of clay fraction, which classified them to loamy soils. The clay content of the Bt horizons lies within the typical range of Luvisols of this area (Dąbkowska-Naskręt and Jaworska, 1997) and is similar as in Bt horizons of Luvisols formed from glacial sediments in NE Germany (Kühn, 2003).

In all pedons soil texture tend to coarsen in upper part and are significantly finer below $40-56 \mathrm{~cm}$. It is also noticeable in depletion of eluvial horizons with clay fraction compared to Bt horizon, which is a diagnostic feature for these horizons (Anderson, 1987). Observed texture non-uniformity in the profiles of the investigated soils may have a primal character related to periglacial processes or it can be a secondary origin related to pedogenesis.

Strong texture contrast within the profiles could point to a lithological discontinuity. Particularly, change in sand content, observed below $40-56 \mathrm{~cm}$ in studied profiles may be related to deposition of material of different origin, because pedogenic processes, in general, do not move sand particles (Birkeland, 1999). However, that feature cannot be used as an evidence of material deposition. To confirm foreign origin of the upper layer, other indexes should be applied.

Eluviation of clay fraction due to lessivage resulted in different texture within pedons. Quenard et al. (2011) reported that lessivage consists of vertical transfer of fine particles ranging in size from less than 2 to $10 \mu \mathrm{m}$.

The data on the clay contents in diagnostic horizons of the studied Luvisols (i.e., E and B horizon) indicate that the particles transfer was of different intensity (Appendix 2). Lessivage is a process that can be broken down into the three elementary processes: particle mobilization, particle transport and particle deposition. The mobilization and deposition are complex combination of dispersion (and mobilization) and flocculation (causing deposition) processes of clay colloids. According to Quenard et al. (2011), migration of soil particles is possible when the values of soil $\mathrm{pH}$ in the $\mathrm{E}$ horizon range from 4.5 to 6.5 and are higher than 6.5 in the $\mathrm{B}$ horizon. Consequently, $\mathrm{pH}$ between 4.5 and 6.5 favour dispersion of soil colloids (including clay particles) and their eluviation down the profile. Conversely, illuviation (deposition of clay minerals) occurs when the $\mathrm{pH}$ is higher than 6.5 , in the conditions which flocculation can occur (Duchaufour, 1956; Soil Survey Staff, 2010). The evolution of pH over time due to either liming in cultivated soils or acidification by vegetation in forested areas impacts these processes. Thus, the intensity of lessivage is different and related to pedoenvironment conditions.

Moreover, particle mobilization is related to the nature of the exchangeable cations in soil. The dominance of monovalent cations accelerates dispersion and eluviation of clay particles and polyvalent cations favours flocculation. But the observed differences are caused not only by this soil forming process. The study carried out in northeastern Germany on genesis of Luvisols showed that the till plains are covered by periglacially formed silty layer (40-60 cm in thickness). The silty cover bed is discussed to be of mostly Holocene pedogenic origin (Helbig, 1999). It is also accepted, that periglacial soil-mixtive processes (e.g., repeated freeze - thaw cycles, cryoturbation), where a slight aeolian input cannot be excluded, led to the formation of the upper $40-60 \mathrm{~cm}$ of the ground, the so-called silty-cover bed. The origin of the upper strata of studied soils developed from boulder loam of the last Vistula (Weichselian) Glaciation, on the

\footnotetext{
* Supplementary data associated with this article can be found, in the online version, at doi: 10.7306/gq.1175
} 

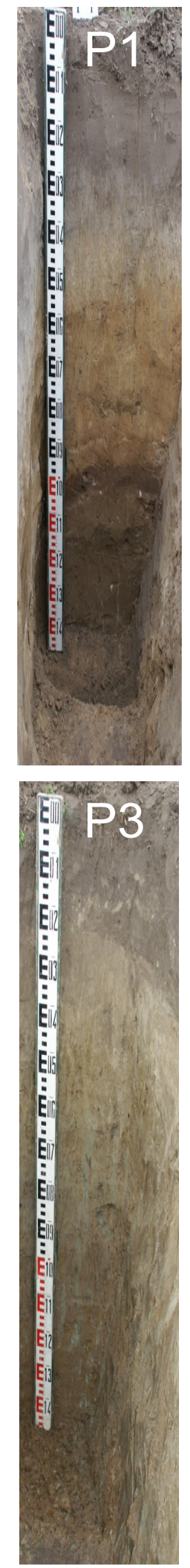

Ap [0-30 cm]

Silt, Munsell color:

moist - 10YR 5/4, dry - 10YR 6/6.

Soil structure medium, moderate, granular. Consistence: soft, boundary clear, smooth. Et $[30-56 \mathrm{~cm}]$

Silt, Munsell color:

moist - 7.5YR 5/3, dry - 10YR 8/4.

Soil structure fine, medium, angular blocky.

Consistence: moderately firm, clear, smooth. 2Bt1 [56-98 cm]

Sandy loam, Munsell color:

moist - 10YR 3/4, dry - 10YR 5/2.

Soil structure medium, angular blocky.

Consistence: firm, boundary clear, smooth. 2Bt2 [98-110 cm]

Sandy loam, Munsell color:

moist - 10YR 6/6, dry-10YR 6/4.

Soil structure medium, angular blocky, strong Consistence: firm, boundary clear, smooth.

\section{Ck [110-150 cm]}

Sandy loam, Munsell color:

moist - 10YR 6/6, dry - 10YR 7/3.

Soil structure medium, angular blocky, strong

Consistence: firm, boundary clear, smooth.

\section{Ap [0-25 cm]}

Silt, Munsell color:

moist - 10YR 2/3, dry - 10YR 4/4

Structure fine, granular, strong.

Consistence soft, boundary clear, smooth.

Etg [25-40 cm]

Silt, Munsell color:

moist - 7.5YR 4/4, dry - 10YR 4/5

Structure fine and medium, angular

and subangular, strong.

Consistence soft, boundary, wavy.

2Btg [40-95 cm]

Sandy loam, Munsell color:

moist - 10YR 4/4, dry - 10YR 6/6.

Structure medium, angular, strong.

Consistence firm, boundary wavy.

2Ckg1 [95-125 cm]

Sandy loam, Munsell color:

moist - 10YR 4/6, dry - 10YR 6/4.

Structure medium, angular, strong

Consistence firm, boundary clear, smooth. 2Ck1 [125-150 cm]

Sandy loam, Munsell color:

moist - 10YR 4/6, dry - 10YR 6/4

Structure medium, angular, strong.

Consistence firm, boundary clear, smooth.

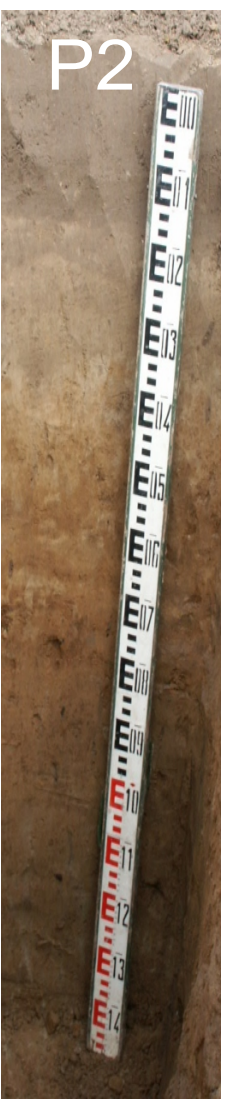

Ap [0-25 cm]

Silt, Munsell color:

moist - 10YR 4/3, dry - 10YR 6/2.

Structure fine, granular, strong.

Consistence soft, boundary clear, smooth

Et [25-43 cm]

Silt, Munsell color:

moist - 10YR 6/3, dry - 10YR 8/2

Structure fine and medium, angular blocky

and subangular blocky, strong.

Consistence soft, boundary clear, smooth

\section{Bt [43-110 cm]}

Sandy loam, Munsell color:

moist - 10YR 4/6, dry - 10YR 8/4

Structure medium, angular blocky, strong

Consistence firm, boundary clear, smooth

2Ck1 [110-130 cm]

Sandy loam, Munsell color:

moist - 10YR 4/6, dry - 10YR 6/4

Structure medium, angular blocky, strong

Consistence firm, boundary clear, smooth

2Ck2 [130-150 cm]

Sandy loam, Munsell color:

moist - 10YR 5/6, dry - 10YR 6/6

Structure medium, angular blocky, strong

Consistence firm, boundary clear, smooth.

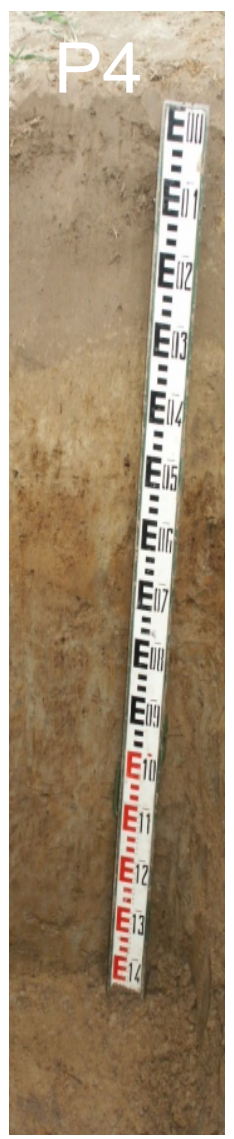

Ap [0-30 cm]

Silt, Munsell color

moist - 10YR 4/3, dry - 10YR 5/2.

Structure fine, granular, strong.

Consistence soft, boundary clear, smooth

Et $[30-50 \mathrm{~cm}$ ]

Silt, Munsell color:

moist - 10YR 5/6, dry - 10YR 5/7.

Structure fine and medium, angular blocky, strong

Consistence soft, boundary clear, wavy.

2Bt [50-80 cm]

Sandy loam, Munsell color:

moist - 10YR 4/6, dry - 10YR 6/6.

Structure medium, angular blocky, strong.

Consistence firm, boundary wavy.

2 Ck1 [80-120 cm]

Sandy loam, Munsell color:

moist - 10YR 5/6, dry - 10YR 5/6.

Structure medium, angular blocky, strong.

Consistence firm, boundary clear, smooth.

2Ck2 [130-150 cm]

Sandy loam, Munsell color:

moist - 10YR 5/8, dry - 10YR 6/6.

Structure medium, angular blocky, strong.

Consistence firm, boundary clear, smooth. 


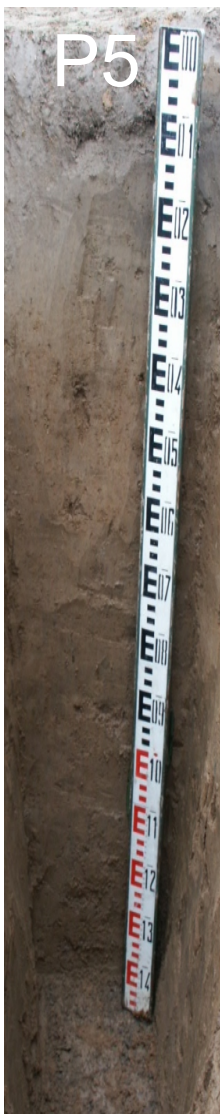

Ap $[0-22 \mathrm{~cm}]$

Silt, Munsell color:

moist - 10YR 5/2, dry - 10YR 8/4.

Structure fine, granular, moderate.

Consistence soft, boundary clear, smooth.

t [22-35 cm]

Silt, Munsell color:

moist - 10YR 4/6, dry - 10YR 6/6.

Structure fine and medium, angular, strong. Consistence soft, boundary clear, smooth

2Bt [35-110 cm]

Sandy loam, Munsell color:

moist - 10YR 6/4, dry - 10YR 7/2.

Structure medium, angular blocky,strong.

Consistence firm, boundary clear, smooth.

2BC [110-130 cm]

Sandy loam, Munsell color:

moist - 10YR 3/4, dry - 10YR 3/4

Structure medium, angular blocky,strong. Consistence firm, boundary clear, smooth. 2Ck [130-150 cm]

Sandy loam, Munsell color:

moist - 10YR 4/6, dry - 10YR 6/4

Structure medium, angular blocky,strong.

Consistence firm, boundary clear, smooth.

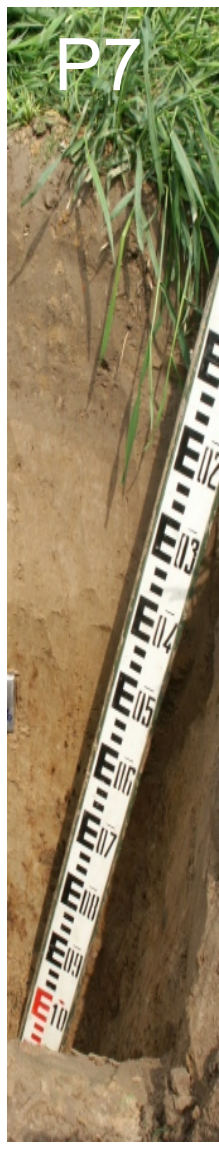

Ap [0-23 cm]

Silt, Munsell color:

moist $-2.5 Y$ $4 / 2$, dry $-2.5 Y 6 / 2$

Structure fine, granular, moderate.

Consistence soft, boundary clear, smooth.

Et [23-43 cm]

Silt, Munsell color:

moist $-2.5 Y 5 / 3$, dry $-2.5 Y 7 / 2$

Structure medium, angular and subangular, strong.

Consistence soft, boundary wavy.

2EBg [43-61 cm]

Sandy loam, Munsell color:

moist $-2.5 Y 5 / 6$, dry $-2.5 Y 7 / 4$.

Structure medium, angular blocky, strong.

Consistence firm, boundary clear, wavy, stones.

2Btg [61-111 cm]

Sandy loam, Munsell color:

moist $-2.5 Y$ 4/4, dry $-2.5 Y 6 / 6$.

Structure coarse, angular blocky, strong.

Consistence firm, boundary wavy, stones.

$2 \mathrm{Cg}[111-150 \mathrm{~cm}]$

Sandy loam, Munsell color:

moist $-2.5 Y 5 / 6$, dry $-2.5 Y 7 / 4$

Structure coarse, angular blocky, strong.

Consistence firm, boundary clear, smooth.

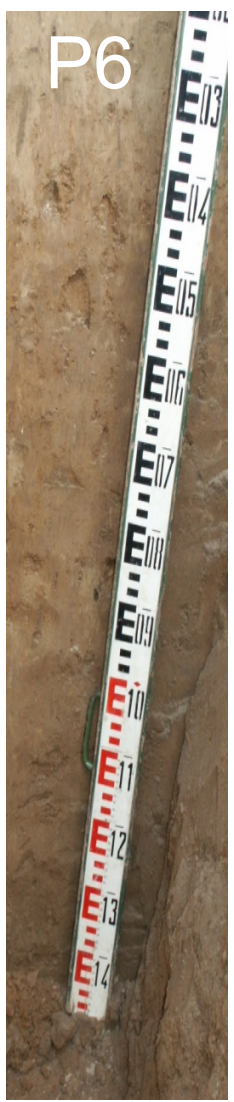

Ap $[0-20 \mathrm{~cm}]$

Silt, Munsell color:

moist - 10YR $8 / 3$, dry - 10YR $8 / 4$

Structure fine, granular, moderate.

Consistdence soft, boundary clear, smooth.

Et [20-42 m]

Silt, Munsell color:

moist - 10YR 6/3, dry - 10YR 7/3

Structure medium, angular, strong.

Consistence soft, boundary clear, smooth.

2EB [42-90 cm]

Sandy loam, Munsell color:

moist - 10YR $7 / 2$, dry - 10YR $7 / 3$

Structure medium, angular blocky, strong.

Consistence firm, boundary wavy.

2Bt [90-130 cm]

Sandy loam, Munsell color:

moist - 10YR 4/6, dry - 10YR 6/4

Structure medium, angular blocky, strong.

Consistence firm, boundary clear, smooth.

2 C2 [130-150 cm]

Sandy loam, Munsell color:

moist - 10YR 4/6, dry - 10YR 6/4.

Structure coarse, angular blocky, strong.

Consistence firm, boundary clear, smooth. 
flat plain, in similar pedoclimatic conditions, could be the same as Luvisols being studied in NE Germany (Kopp and Kowalkowski, 1990; Kühn, 2001).

Lithologic discontinuity described as distinct change in texture and differences in soil morphology can be also identified on the base of chemical composition of the soil (Komisarek, 2000). For the estimation of changes in chemical composition within profile, only contents of hardly weathered components are regarded in studied soils (Table 1).

Chemical analysis of the bulk soils indicates that $\mathrm{SiO}_{2}$ dominates and its content was in range 71.4 to $88.6 \%$ (Table 1). Usually content of $\mathrm{SiO}_{2}$ decreases along with the depth in a soil profile. The highest amounts of silica were detected in surface and eluvial horizons. Moreover, in these horizons sand and coarse silt, rich in silica predominant. Lower content of this ingredient was observed in Bt horizon of the investigated soils, which is a result of different texture (Marion et al., 1976) and accumulation of clay fraction in Bt horizons (Komisarek and Szałata, 2011).

Additionally, a good evidence that two different materials are present in the profiles are changes in the contents of silicon, aluminum, iron, titanium and zirconium oxides in each of the horizon related to parent material content (Table 2). It was observed a significant difference in the calculated values between two strata: upper - and lower at 40-56 cm below the surface.

Commonly, Ti, Zr or rare earth groups of elements are used as index of soil genetic uniformity. In studied soils the content of $\mathrm{TiO}_{2}$ (Table 1) within the profiles is fairy uniform, without clear patterns in the profile distribution. Slightly enrichment of illuvial horizons with $\mathrm{TiO}_{2}$ was observed in three of the investigated profiles (P1, P2, P4), which is also reported by other authors (Czarnowska, 1989; Dąbkowska-Naskręt and Jaworska, 2001). Ti tends to be enriched in the finer fractions $(<20 \mu \mathrm{m})$ easily transported down the profile during lessivage. Such a scenario is confirmed by the lack of statistical correlation between Ti content and coarse grains amounts (sand and silt fractions) in studied soils. Furthermore, there was no statistically significant correlation between the content of $\mathrm{Ti}$ and clay fraction. The results showed that $\mathrm{Ti}$ content as the indicator of soil material uniformity or lithological discontinuity within studied profiles cannot be used, due to its mobility.

Ta ble 1

Content of $\mathrm{SiO}_{2}, \mathrm{Al}_{2} \mathrm{O}_{3}, \mathrm{Fe}_{2} \mathrm{O}_{3}, \mathrm{TiO}_{2}$ and $\mathrm{ZrO}_{2}$ in the soil material (fraction $\varnothing<2 \mathrm{~mm}$ )

\begin{tabular}{|c|c|c|c|c|c|c|c|c|}
\hline No. & Horizon & $\begin{array}{c}\text { Depth } \\
\text { [cm] }\end{array}$ & $\begin{array}{l}\mathrm{SiO}_{2} \\
{[\%]} \\
\end{array}$ & $\begin{array}{c}\mathrm{Al}_{2} \mathrm{O}_{3} \\
{[\%]}\end{array}$ & $\begin{array}{c}\mathrm{Fe}_{2} \mathrm{O}_{3} \\
{[\%]}\end{array}$ & $\begin{array}{l}\mathrm{TiO}_{2} \\
{[\%]} \\
\end{array}$ & $\begin{array}{c}\mathrm{ZrO}_{2} \\
{[\%]}\end{array}$ & $\begin{array}{l}\mathrm{Ti} \\
\mathrm{Zr}\end{array}$ \\
\hline \multirow{5}{*}{ P1 } & $A p$ & $0-30$ & 82.2 & 5.11 & 1.13 & 0.27 & 0.015 & 2.89 \\
\hline & Et & $30-56$ & 3.3 & .81 & 1.02 & 0.36 & 028 & 2.04 \\
\hline & 2Bt1 & $56-98$ & 4.6 & 7.66 & 2.29 & 0.43 & 0.018 & 3.79 \\
\hline & $2 \mathrm{Bt} 2$ & $98-110$ & 5.4 & 8.51 & 2.09 & 0.46 & 0.013 & 5.66 \\
\hline & $2 \mathrm{Ck}$ & $110-150$ & 87.2 & 6.23 & 1.92 & .36 & 013 & 4.55 \\
\hline \multirow{5}{*}{ P2 } & $\mathrm{Ap}$ & $0-25$ & 36.6 & .98 & 0.81 & 0.34 & 0.019 & 2.70 \\
\hline & $\mathrm{Et}$ & $25-43$ & 78.6 & 6.46 & 2.38 & 0.34 & 020 & 3.21 \\
\hline & $2 \mathrm{Bt}$ & $43-110$ & 76.5 & 5.92 & 2.09 & 0.42 & 0.013 & 4.61 \\
\hline & 2Ck1 & $110-130$ & 79.6 & 96 & 1.32 & .37 & & .40 \\
\hline & 2Ck2 & $130-150$ & 74.5 & 4.74 & 1.89 & 0.30 & 016 & 3.02 \\
\hline \multirow{5}{*}{ P3 } & & & & & & & & 23 \\
\hline & Et & $25-40$ & 84.0 & 4.72 & 1.15 & 0.51 & 0.022 & 3.65 \\
\hline & $2 \mathrm{Btg}$ & & 76.6 & 7.37 & 2.29 & 0.47 & & 3.79 \\
\hline & $2 \mathrm{Ckg} 1$ & $95-125$ & 78.2 & 6.84 & 2.05 & 0.51 & 0.013 & 3.98 \\
\hline & $2 \mathrm{Ck} 2$ & $125-150$ & 71.4 & .63 & 2.20 & 0.37 & 012 & 5.07 \\
\hline \multirow{5}{*}{ P4 } & & $0-30$ & 80.4 & 5.28 & 1.11 & 0.34 & & 2.48 \\
\hline & Et & $30-50$ & 83.8 & 5.86 & 1.49 & 0.40 & 0.023 & 3.12 \\
\hline & $2 \mathrm{Bt}$ & $50-80$ & 79.5 & 7.44 & 2.28 & 0.41 & 015 & 4.37 \\
\hline & 2Ck1 & $80-120$ & 76.8 & 7.42 & 2.03 & 0.40 & 0.017 & 3.45 \\
\hline & $2 \mathrm{Ck} 2$ & $120-150$ & 73.6 & 6.92 & 1.59 & 0.45 & & 3.74 \\
\hline \multirow{5}{*}{ P5 } & $\mathrm{An}$ & $0-22$ & 84.0 & 7.33 & 1.19 & 0.41 & 0.022 & 2.80 \\
\hline & $\mathrm{Et}$ & $22-35$ & 78.2 & 5.94 & 1.16 & 0.34 & 023 & 2.81 \\
\hline & $2 \mathrm{Bt}$ & $35-110$ & 76.4 & 7.98 & 2.34 & 0.33 & 0.013 & 5.27 \\
\hline & $2 \mathrm{BC}$ & $110-130$ & 78.8 & 7.14 & 2.12 & 0.35 & 0.014 & 4.03 \\
\hline & $2 \mathrm{Ck}$ & $130-150$ & 76.5 & 8.70 & 2.26 & 0.39 & & 4.47 \\
\hline \multirow{5}{*}{ P6 } & & & 86.3 & 5.15 & 1.30 & 0.41 & & 2.30 \\
\hline & & $20-42$ & 86.4 & 5.48 & 1.14 & 0.43 & 0.021 & 2.89 \\
\hline & $2 \mathrm{~EB}$ & $42-90$ & 74.9 & 6.95 & 1.90 & 0.35 & 0.020 & 2.63 \\
\hline & $2 \mathrm{Bt}$ & $90-130$ & 70.8 & 7.11 & 1.19 & 0.39 & 0.012 & 4.05 \\
\hline & $2 \mathrm{C}$ & $130-150$ & 71.0 & 6.46 & 1.30 & 0.32 & & 3.52 \\
\hline \multirow{5}{*}{ P7 } & Ap & $0-23$ & 86.6 & 4.98 & 1.75 & 0.40 & 0.022 & 2.13 \\
\hline & Et & $23-43$ & 86.4 & 5.10 & 1.98 & 0.39 & 0.027 & 2.01 \\
\hline & 2EBg & & 80.7 & 6.36 & 3.08 & 0.33 & 0.023 & 2.92 \\
\hline & $2 \mathrm{Btg}$ & $61-111$ & 79.6 & 6.45 & 2.72 & 0.32 & 0.015 & 3.20 \\
\hline & $2 \mathrm{Cg}$ & $111-150$ & 79.1 & 4.79 & 2.65 & 0.31 & 0.016 & 2.66 \\
\hline
\end{tabular}


Estimated changes of oxides content in relation to the deepest horizon in pedon $(100 \%)$

\begin{tabular}{|c|c|c|c|c|c|c|c|}
\hline No. & Horizon & $\begin{array}{l}\text { Depth } \\
\text { [cm] }\end{array}$ & $\begin{array}{l}\mathrm{SiO}_{2} \\
{[\%]}\end{array}$ & $\begin{array}{c}\mathrm{Al}_{2} \mathrm{O}_{3} \\
{[\%]}\end{array}$ & $\begin{array}{c}\mathrm{Fe}_{2} \mathrm{O}_{3} \\
{[\%]}\end{array}$ & $\begin{array}{l}\mathrm{TiO}_{2} \\
{[\%]}\end{array}$ & $\begin{array}{c}\mathrm{ZrO}_{2} \\
{[\%]}\end{array}$ \\
\hline \multirow{5}{*}{ P1 } & Ap & $0-30$ & 94.2 & 82.0 & 58.9 & 75.0 & 115.0 \\
\hline & Et & $30-56$ & 95.5 & 77.2 & 53.1 & 100.0 & 215.0 \\
\hline & $2 \mathrm{Bt} 1$ & $56-98$ & 85.5 & 122.9 & 119.3 & 119.4 & 138.0 \\
\hline & $2 \mathrm{Bt} 2$ & $98-110$ & 86.5 & 136.6 & 108.9 & 127.8 & 100.0 \\
\hline & $2 \mathrm{Ck}$ & $110-150$ & & & & & \\
\hline \multirow{5}{*}{ P2 } & Ap & $0-25$ & 116.0 & 82.1 & 42.9 & 113.3 & 118.0 \\
\hline & $\mathrm{Et}$ & $25-43$ & 105.0 & 136.3 & 125.9 & 113.3 & 125.0 \\
\hline & $2 \mathrm{Bt}$ & $43-110$ & 102.7 & 124.9 & 110.6 & 140.0 & 81.0 \\
\hline & $2 \mathrm{Ck} 1$ & $110-130$ & 106.8 & 104.6 & 69.8 & 123.3 & 87.0 \\
\hline & 2Ck2 & $130-150$ & & & & & \\
\hline \multirow{5}{*}{ P3 } & $A p$ & $0-25$ & 124.1 & 54.1 & 52.3 & 81.1 & 150.0 \\
\hline & Etg & $25-40$ & 117.4 & 61.9 & 52.3 & 137.8 & 183.0 \\
\hline & $2 \mathrm{Btg}$ & $40-95$ & 107.3 & 96.6 & 104.1 & 127.0 & 133.0 \\
\hline & 2Ckg1 & $95-125$ & 109.5 & 89.4 & 93.2 & 137.8 & 108.0 \\
\hline & 2Ck2 & $125-150$ & & & & & \\
\hline \multirow{5}{*}{ P4 } & $A p$ & $0-30$ & 109.2 & 76.3 & 69.8 & 75.6 & 178.0 \\
\hline & Et & $30-50$ & 113.8 & 84.7 & 93.7 & 88.9 & 164.0 \\
\hline & $2 \mathrm{Bt}$ & $50-80$ & 108.0 & 107.5 & 143.4 & 91.1 & 107.0 \\
\hline & $2 \mathrm{Ck} 1$ & $80-120$ & 104.3 & 107.2 & 127.7 & 80.0 & 121.0 \\
\hline & 2Ck2 & $120-150$ & & & & & \\
\hline \multirow{5}{*}{ P5 } & Ap & $0-22$ & 109.8 & 84.3 & 52.7 & 105.1 & 157.0 \\
\hline & Et & $22-35$ & 102.2 & 68.3 & 51.3 & 87.2 & 164.0 \\
\hline & $2 \mathrm{Bt}$ & $35-110$ & 99.8 & 91.7 & 103.5 & 84.6 & 93.0 \\
\hline & $2 \mathrm{BC}$ & $110-130$ & 103.0 & 82.1 & 93.8 & 89.7 & 100.0 \\
\hline & $2 \mathrm{Ck}$ & $130-150$ & & & & & \\
\hline \multirow{5}{*}{ P6 } & Ap & $0-20$ & 121.5 & 79.7 & 100.0 & 128.1 & 150.0 \\
\hline & Et & $20-42$ & 121.6 & 84.8 & 87.7 & 134.4 & 150.0 \\
\hline & 2EB & $42-90$ & 105.5 & 107.6 & 146.2 & 109.4 & 143.0 \\
\hline & $2 \mathrm{Bt}$ & $90-130$ & 99.7 & 110.1 & 91.5 & 121.9 & 86.0 \\
\hline & $2 \mathrm{C}$ & $130-150$ & & & & & \\
\hline \multirow{5}{*}{ P7 } & Ap & $0-23$ & 109.5 & 103.9 & 66.0 & 129.0 & 137.0 \\
\hline & Et & $23-43$ & 109.2 & 106.5 & 74.7 & 125.8 & 169.0 \\
\hline & $2 \mathrm{EBg}$ & $43-61$ & 102.0 & 132.8 & 116.2 & 106.5 & 144.0 \\
\hline & 2Btg & $61-111$ & 100.6 & 134.7 & 102.6 & 103.2 & 63.0 \\
\hline & $2 \mathrm{Cg}$ & $111-150$ & & & & & \\
\hline
\end{tabular}

For the satisfactory confirmation of the hypothesis about the lithological discontinuities another criterion has been applied i.e. $\mathrm{Zr}$ distribution. Zirconium occurs principally in more resistant to weathering mineral - zircon $\left(\mathrm{ZrSiO}_{4}\right)$. The amount of $\mathrm{Zr}$ has been assumed to be uniform throughout all horizons of a soil profile in soils formed from the materials of the same origin (Stiles et al., 2003).

The total content of $\mathrm{Zr}$ in the investigated soils was in the range of 95.13 to $212.15 \mathrm{mg} \mathrm{kg}^{-1}$ (Table 3 ) and is characteristic for Polish soils formed from boulder material (Jaworska and Dąbkowska-Naskręt, 2006). It was observed that underlaying material contains lower amounts of $\mathrm{Zr}$ (Table 3). The boundary between $\mathrm{Zr}$ contents within each soil profile occurs at the same depth as the abrupt change in sand grains contents i.e. $40-56 \mathrm{~cm}$. Thus, the vertical distribution of $\mathrm{Zr}$ confirms different origin of soil material. Chapman and Horn (1968) stated that minerals which contain zirconium mostly occur in silt fraction $(\varnothing 0.05-0.002 \mathrm{~mm})$ and the same trends were observed in studied Luvisols. Statistical analysis showed positive correlation between $\mathrm{Zr}$ content and silt fraction (correlation coefficient: 0.692384; $p<0.05$ ). Moreover, $\mathrm{Zr}$ content
The total content of zirconium in soils

\begin{tabular}{|c|c|c|c|c|}
\hline No. & Horizon & $\begin{array}{c}\text { Depth } \\
{[\mathrm{cm}]}\end{array}$ & $\begin{array}{c}\mathrm{Zr} \\
{\left[\mathrm{mg} \cdot \mathrm{kg}^{-1}\right]}\end{array}$ & $\mathrm{Zr} / \mathrm{Zr} \mathrm{p}^{*}$ \\
\hline \multirow{5}{*}{ P1 } & $A p$ & $0-30$ & 111.23 & 1.17 \\
\hline & Et & $30-56$ & 212.15 & 2.23 \\
\hline & $2 \mathrm{Bt} 1$ & 56-98 & 136.34 & 1.43 \\
\hline & $2 \mathrm{Bt} 2$ & $98-110$ & 98.44 & 1.03 \\
\hline & $2 \mathrm{Ck}$ & $110-150$ & 95.13 & \\
\hline \multirow{5}{*}{ P2 } & $A p$ & $0-25$ & 149.59 & 0.65 \\
\hline & Et & $25-43$ & 155.94 & 0.68 \\
\hline & $2 \mathrm{Bt}$ & $43-110$ & 97.15 & 0.42 \\
\hline & $2 \mathrm{Ck} 1$ & $110-130$ & 107.08 & \\
\hline & 2Ck2 & $130-150$ & 121.99 & \\
\hline \multirow{5}{*}{ P3 } & Ap & $0-25$ & 135.79 & 0.69 \\
\hline & $\mathrm{Et}$ & $25-40$ & 166.19 & 0.85 \\
\hline & $2 \mathrm{Bt}$ & $40-95$ & 117.99 & 0.60 \\
\hline & 2Ckg1 & $95-125$ & 102.12 & \\
\hline & 2Ck2 & $125-150$ & 94.39 & \\
\hline \multirow{5}{*}{ P4 } & $A p$ & $0-30$ & 193.15 & 0.83 \\
\hline & Et & $30-50$ & 170.75 & 0.73 \\
\hline & $2 \mathrm{Bt}$ & $50-80$ & 110.12 & 0.47 \\
\hline & 2Ck1 & $80-120$ & 127.60 & \\
\hline & $2 \mathrm{Ck} 2$ & $120-150$ & 105.29 & \\
\hline \multirow{5}{*}{ P5 } & $A p$ & $0-22$ & 167.49 & 1.62 \\
\hline & $\mathrm{Et}$ & $22-35$ & 175.35 & 1.69 \\
\hline & $2 \mathrm{Bt}$ & $35-110$ & 96.18 & 0.93 \\
\hline & $2 \mathrm{BC}$ & $110-130$ & 102.81 & 0.99 \\
\hline & $2 \mathrm{Ck}$ & $130-150$ & 103.59 & \\
\hline \multirow{5}{*}{ P6 } & $A p$ & $0-20$ & 158.65 & 1.49 \\
\hline & Et & $20-42$ & 161.46 & 1.52 \\
\hline & 2EB & $42-90$ & 150.79 & 1.42 \\
\hline & $2 \mathrm{Bt}$ & $90-130$ & 93.52 & 0.88 \\
\hline & $2 \mathrm{C}$ & $130-150$ & 106.26 & \\
\hline \multirow{5}{*}{ P7 } & Ap & $0-23$ & 168.45 & 1.32 \\
\hline & Et & $23-43$ & 201.07 & 1.61 \\
\hline & $2 \mathrm{EBg}$ & 43-61 & 173.83 & 1.39 \\
\hline & $2 \mathrm{Btg}$ & $61-111$ & 112.93 & 0.90 \\
\hline & $2 \mathrm{Cg}$ & $111-150$ & 124.89 & \\
\hline
\end{tabular}

* - ratio of $\mathrm{Zr}$ concentration in genetic horizon to $\mathrm{Zr}$ concentration in the parent material

was negatively correlated with clay fraction (correlation coefficient: $-0.668157 ; p<0.05$ ).

Distribution of $\mathrm{Zr}$ is also related to the loss of less resistant material during weathering; as a result $\mathrm{Zr}$ concentrations in the upper horizons relatively increase (Stiles et al., 2003). To exclude the impact of such a process on different contents of $Z r$ in upper and lower parts of studied pedons, it was necessary to apply more stable index. Other authors (Chapman and Horn, 1968; Brimhall et al., 1991) used the Ti/Zr relationship to asses soil material uniformity. The ratio $\mathrm{Ti} / \mathrm{Zr}$ should remain stable (constant) throughout profile depth, confirming soil material uniformity. In the present study a difference in the values of this index calculated for upper horizons compared to the lower horizons supports the hypothesis on different origin of material from the upper and lower layer (Table 1).

The lithologic discontinuity within profiles of the investigated soils has been additionally confirmed by X-ray analysis of the 

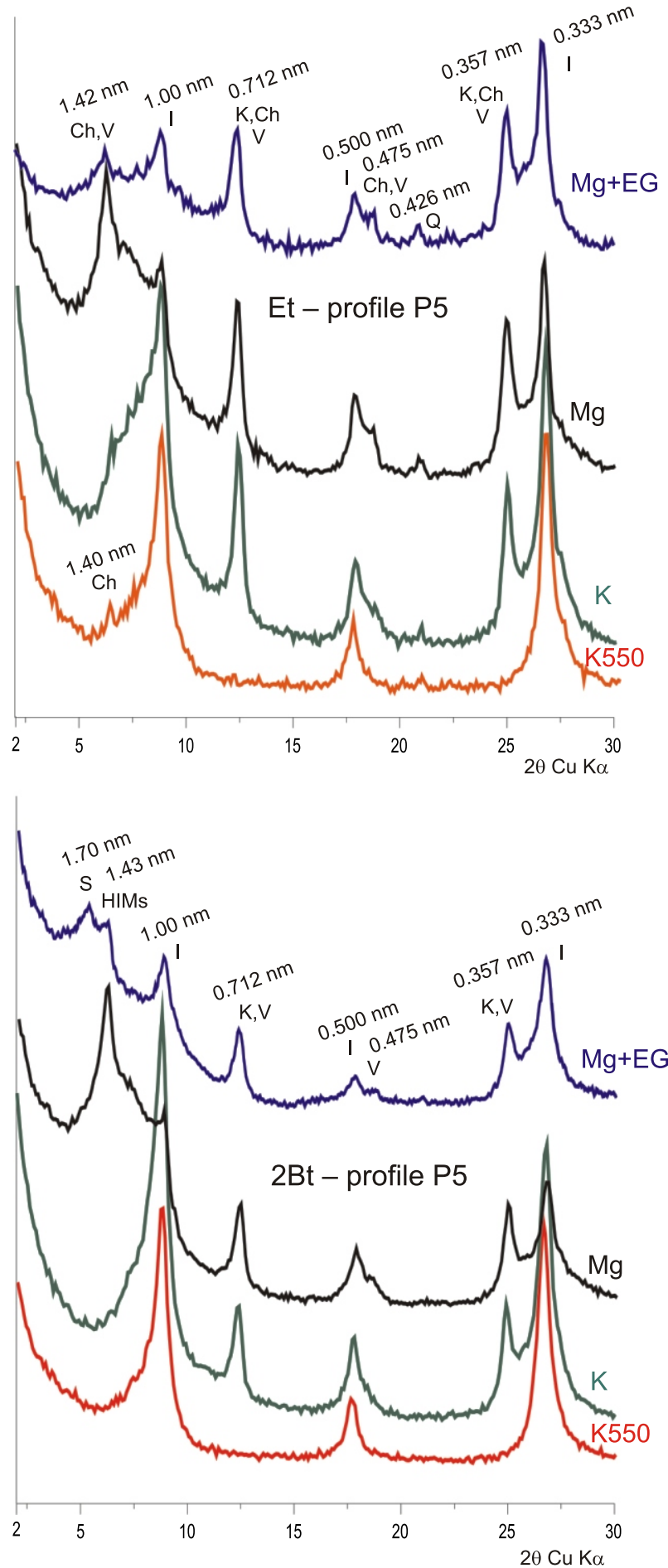

Fig. 4. X-ray diffractograms of clay fraction $(<2.0 \mu \mathrm{m})$ from $E t$ and $2 \mathrm{Bt}$ horizons of profile $\mathrm{P} 5$

$\mathrm{K}$ - potassium saturated; $\mathrm{K} 550$ - potassium saturated and heated at $550^{\circ} \mathrm{C} ; \mathrm{Mg}$ - magnesium saturated; $\mathrm{Mg}+\mathrm{EG}$ - magnesium saturated and ethylene glycol-solvated; $\mathrm{Ch}$ - chlorite, $\mathrm{H} / \mathrm{Ms}$ - hydroxy interlayer minerals, I - illite, $\mathrm{K}$ - kaolinite, S - smectite, V - vermiculite clay fraction since chlorite was found only in the Ap and Et horizons, which cover the silty layer of soil profiles (Fig. 4). The XRD pattern of Mg-saturated samples after ethylene glycol solvation, showed d-spacing $1.7 \mathrm{~nm}$, which indicates the presence of smectite. Otherwise, after K-saturated samples were heated at $550^{\circ} \mathrm{C}$, the $1.4 \mathrm{~nm}$ XRD peak shifted to low d-spacing and the intensity of the $1.0 \mathrm{~nm}$ peak increased, which indicates the presence of vermiculite. Moreover, hydroxy-interlayer minerals (HIMs) were detected in the Bt horizon (Fig. 4). When clay samples were heated to $550^{\circ} \mathrm{C}$, the $1.4 \mathrm{~nm}$ peak collapsed and shifted towards $1.0 \mathrm{~nm}$ promoting the loss of hydroxy-interlayer materials (Barnhisel and Bertsch, 1989). Finally, chlorite and quartz can be identified after $550^{\circ} \mathrm{C}$ treatment due to the presence of small peak around $1.4 \mathrm{~nm}$ and another one at $0.426 \mathrm{~nm}$.

Illite and illite-smectite or illite-vermiculite accounted for about $50 \%$ of all the clay minerals in the clay fraction. The other minerals present in all studied samples include smectite, vermiculite and other mixed-layer minerals.
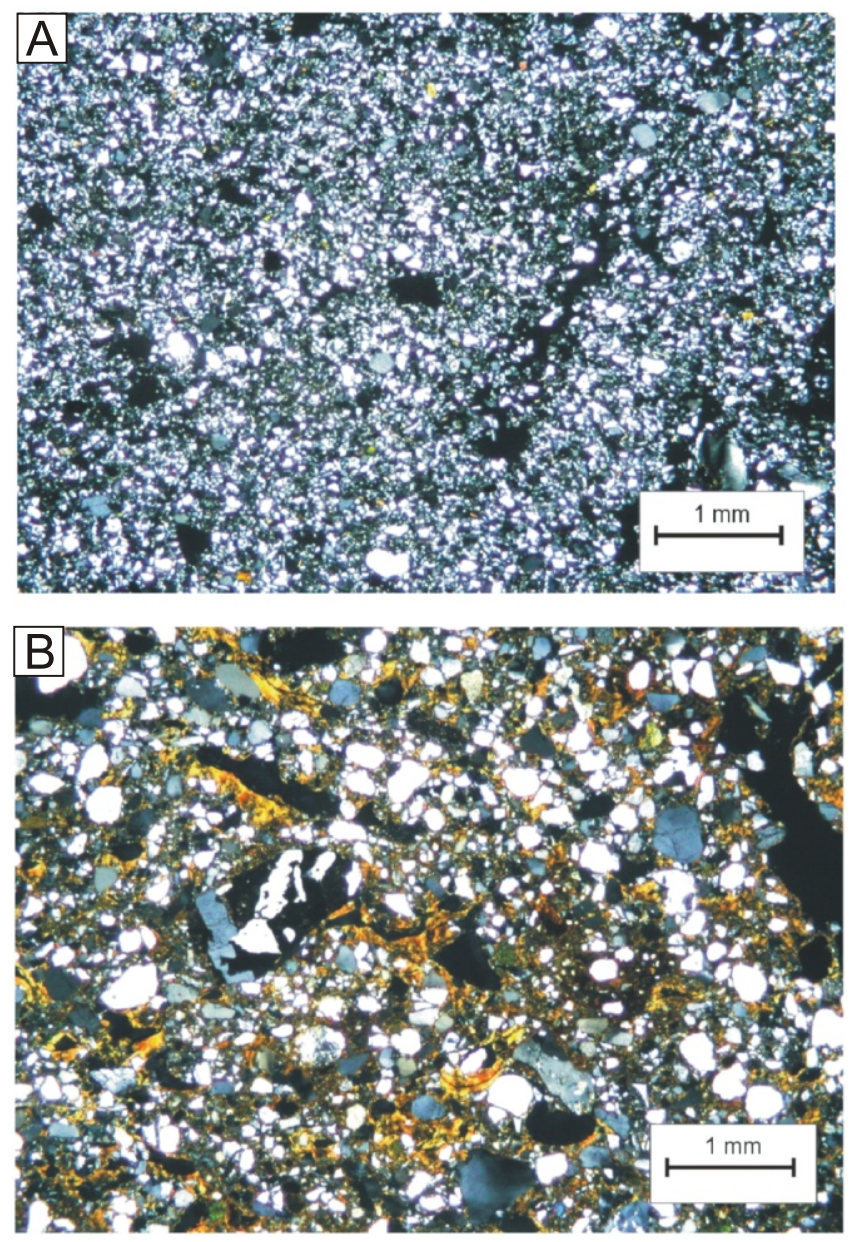

Fig. 5A - soil material from Et horizon of the profile P1; $B$ - soil material from $2 \mathrm{Bt}$ horizon of the profile $\mathrm{P1}$

Cross polarizing light (XPL) 
The micromorphological analysis confirmed the complex genesis of the studied soils. The upper part of the profiles with silty texture contains well- or medium-rounded grains of quartz and a few grains of weathered potassium feldspars (Fig. 5A) Under that layer which forms the Ap and Et horizons one can find deposits of glacial till with medium- or poorly-rounded grains of quartz, a few grains of feldspars and plagioclases without clear evidence of weathering (Fig. 5B).

Aditionally, higher amount of coarse grains of quartz under the discontinuity have occurred.

Micromorphological image of Bt sample shows the presence of clay coatings and infillings - very characteristic for clay iluviation (Fig. 5A). Clay coatings and clay infillings are optically well-oriented. The presence of numerous forms of oriented colloidal clay is typical for the Bt diagnostic horizon (IUSS Working Group WRB, 2006). The micromass of Bt horizon is composed of clay domains enriched with iron oxides. Clay domains are oriented parallel to the walls of the channels forming porostriated b-fabric. The occurrence of such orientation of soil micromass indicates that the translocation of clay minerals and iron oxides (during lessivage) to the lower part of the soil profile has occurred.

The results of the laboratory analyses evaluated for trends relating to parent material differences observed in seven pedons support the presence and position of lithologic discontinuity identified by field observation. Distribution patterns of several soil components, clay mineralogy and micromorphology, collectively, indicate that the boundary between two layers of different origin occurs at the depth of $40-56 \mathrm{~cm}$ in studied Luvisols.

\section{CONCLUSIONS}

The results of the study clearly showed an overall inhomogeneity and stratification of the soils. Studied Luvisols developed on the area of Vistula Glaciation did not form as weathering product of homogeneous bedrock.

An abrupt change in texture and vertical differentiation of mineral material are the results of different origin of the upper part of the solum as well as the lessivage. Lithological discontinuity was confirmed by several criteria: $\mathrm{Zr}$ content, $\mathrm{Ti} / \mathrm{Zr}$ ratio within soil profiles, chemical composition of soil material and the mineralogical composition of clay fraction. Photomicrographs of thin sections gave the evidence of clay translocation.

The above study indicated fairy complex origin of the studied soils.

Acknowledgment. The study was financed by the Ministry of Science and Higher Education No 0700/P06/2003/25. The authors appreciate the constructive comments and suggestions from the anonymous reviewers of the manuscript.

\section{REFERENCES}

Anderson, D.W., 1987. Pedogenesis in the grassland and adjacent forest of the Great Plains. Advances in Soil Science, 7: 53-93.

Barnhisel, R.I., Bertsch, P.M., 1989. Chlorite and hydroxyinterlayered vermiculite and smectite. In: Minerals in Soil Environments (eds. J.B. Dixon and S.B. Weed). SSSA Book Ser., 1: 729-788.

Birkeland, P.W., 1999. Soils and Geomorphology. 3rd. ed. Oxford University Press, New York.

Breemen, N., van, Buurman, P., 1998. Soil Formation. Kluwer, Dordrecht.

Brimhall, G.H., Lewis, C.J., Ford, C., Bratt, J., Taylor, G., Warin, O., 1991. Quantitative geochemical approach to pedogenesis: importance of parent material reduction, volumetric expansion and eolian influx. Geoderma, 51: 51-91.

Brindley, G.W., 1980. Quantitative X-ray mineral analysis of clays. Mineralogical Society Monograph, 5: 411-438.

Chapman, S.C., Horn, M.E., 1968. Parent material uniformity and origin of silty soils in northwest Arkansas based on zirconiu-titanium contents. Soil Science Society of America Proceedings, 32: $265-271$

Cremeens, R.L., Mokma, D.L., 1986. Argillic horizon expression and classification in the soils of two Michigan hydrosequences. Soil Science Society of America Journal, 50: 1002-1007.

Crock, J.G., Severson, R.C., 1980. Four reference soil and samples for measuring element availability from western Energy Regions. Geological Survey Circular, 841.

Czarnowska, K., 1989. Content of some metals in soils developed from silty formations (in Polish with English summary). Soil Science Annual, 40: 106-117.

Dąbkowska-Naskręt, H., Jaworska, H., 1997. Lessive soils formed from silt deposits of Pojezierze Chełmińsko-Dobrzyńskie and Wysoczyzna Kaliska region (in Polish with English summary). Part I. Morphology and physico-chemical properties. Soil Science Annual, 48: 59-69.
Dąbkowska-Naskret, H., Jaworska, H., 2001. Titanium in Alfisols formed from glacial deposits of different ages in Poland. Quaternary International, 78: 61-67.

Duchafour, Ph., 1956. Pedologie: applications forestieres et agricoles. Nancy, Ecole Eaux Forestiere.

FitzPatrick, E.A., 1984. Soil Micromorphology. Chapman and Hall Press, London.

Galon, R., 1972. Geomorfologia Polski. Niż Polski, tom 2 (in Polish). PWN, Warszawa.

Helbig, H., 1999. Die spätglaziale und holozäne Überprägung der Grundmoränenplatten in Vorpommern. Greifswalde Geographische Arbeiten, 17: 1-110

IUSS Working Group WRB, 2006 update 2007. World reference base for soil resources 2006. World Soil Resources Reports No.103. FAO, Rome.

Jackson, M.L., 1973. Soil Chemical Analysis - Advanced Course. Department of Soil Science, University of Wisconsin, Madison.

Jaworska, H., Dąbkowska-Naskręt, H., 2006. Zirconium in alfisols of different granulometric composition within soil profiles. Polish Journal of Environmental Studies, 15: 312-315.

Komisarek, J., 2000. Evolution of Luvisols and black earths properties and groundwater chemistry at undulated moraine Lake Poznan. Roczniki AR, Poznań, Rozprawy Naukowe, 307.

Komisarek, J., Szałata, S., 2011. Skład chemiczny masy glebowej wybranych gleb płowych zaciekowych Wielkopolski (in Polish). Nauka Przyroda Technologie, 5/5: 1-16.

Kondracki, J., 2002. Geografia Regionalna Polski (in Polish). PWN, Warszawa.

Kopp, D., Kowalkowski, A., 1990. Cryogenic and pedogenic perstruction in Tertiary and Quaternary deposits, as exemplified in the outcrop of Sternebeck. Quaternary Studies in Poland, 9: $51-71$.

Kühn, P., 2001. Grundlegende Voraussetzungen bodengenetischer Vergleichsuntersuchungen: Theorie und Anwendung. Greifswalde Geographische Arbeiten, 23: 133-153. 
Kühn, P., 2003. Micromorphology and Late Glacial, Holocene Genesis of Luvisols in Mecklenburg-Vorpommern (NE-Germany). Catena, 54: 537-555.

Kuzila, M.S., 1995. Identification of multiple loess units within modern soils of Clay County, Nebraska. Geoderma, 65: 45-57.

Lindner, L., 1984. An outline of Pleistocene chronostratigraphy in Poland. Acta Geologica Polonica, 34: 27-50.

Lindner, L., Marks, L., 1996. Stadials and interstadials of the Wisła Glaciation (Vistulian) in the Polish Lowland and the Tatra Mts. In: Genesis, Lithology and Stratigraphy of Quaternary Deposits: 177-189. Wydawnictwo Naukowe UAM.

Mapa Gleb Polski 1:300,000, 1961. Arkusz C3 (in Polish). IUNG Puławy, Wyd. Geol., Warszawa.

Marion, G.M., Hendricks, D.M., Dult, G.R., Fuller, W.H., 1976. Aluminium and silica solubility in soils. Soil Science, 121: 76-85.

Marks, L., 2002. Last Glacial Maximum in Poland. Quaternary Science Reviews, 21: 103-110.

Muhs, D.R., Bettis, E.A., Been, J., Mc Geehin, J.P., 2001. Impact of climate and parent material on chemical weathering in loess-derived soils of the Mississippi River Valley. Soil Science Society of American Journal, 65: 1761-1777.

Munsell Soil Color Chart, 1994. Munsell Color Company.

Polish Norm PN-ISO 11277, 2005. Soil quality - determination of soil texture - with the areometer-sieve method. PKN, Warszawa.

Polish Soil Classification, 2011. Soil Science Annual, LXII/3.

Quenard, L., Samouelian, A., Laroehe, B., Cornu, S., 2011. Lessivage as a major process of soil formation: a revisitation of existing data. Geoderma, 167/168: 135-147.
Schaetzl, R.J., Mokoma, D.I., 1998. A numerical index of Podzol and Podzolic soil development. Physical Geography, 35: 183-191.

Semmel, A., 2004. Periglacial past and geoecological present of soils in German Lower Mountain Ranges. Monitoring Środowiska Przyrodniczego, 5: 235-247.

Skłodowski, P., Bielska, A., 2009. Properties and fertility of soils in Poland - a basis for the formation of agro-environmental relations (in Polish with English summary). Water-Environment-Rural Area, 9: 203-214.

Soil Survey Staff, 2010. Keys to Soil Taxonomy. USDA, National Resource Conservation Service. 11th ed. National Soil Survey Center, Lincoln, NE.

Stiles, C.A., Mora, C.I., Driese, S.G., 2003. Pedogenic processes and domain boundaries in a Vertisol climosequence: evidence from titanium and zirconium distribution and morphology. Geoderma, 116: 279-299.

Stoops, G., 2003. Guidelines for analysis and description of soil and regolith thin sections. Soil Science Society of America, Madison, Wisconsin.

Wang, Z.P., Shi, L.L., Chen, G.S. Cheng, K.L., 2000. Multivariate spectrofluorimetry of ultra trace zirconium (IV) and hafnium(IV) assisted by several chemometrics methods. Talanta, 51: 315-326.

Wysota, W., Molewski, P., Sokołowski, R.J., 2008. Vistula lobe dynamics during the last glaciation in the light of new research. Landform Analysis, 19: 264-266. 